\title{
V kưži posledního mluvčího. Gamifikace výstavy o jazykové diverzitě ${ }^{1}$
}

Martina Vokáčová, Jakub Jehlička, Jan Bičovský, Eva Lehečková

\section{In the shoes of the last speaker. Gamifying a linguistic diversity exhibition.}

Abstract: In this paper, we deal with the presentation of the topics of the diversity, endangerment, extinction, documentation and preservation of the world's languages to the primary and secondary school students via experiential education. We present an interactive exhibition titled "Linguistic biosphere" accompanied by an escape game "The last speaker". The exhibition and the escape game were organized by the educational platform Library of Languages for the 2019 European Day of Languages festival in Kampus Hybernská. The paper describes how the current approaches to linguistic diversity and the principles of experiential learning theory and gamification were utilized in the design of the particular components of the exhibition and the escape game.

Keywords: endangered languages, popularization, gamification, experiential learning, escape room

1 Tato studie vznikla za podpory projektu Univerzity Karlovy Progres Q10, Jazyk v proměnách času, místa, kultury.

$2 \mathrm{~V}$ plném znění pro jednotlivé typy škol dostupné zde: http:// www.nuv.cz/t/rvp.

3 Viz napr. https://www.sil. org/about/endangered-languages\#node-65541

Mgr. Martina Vokáčová Filozofická fakulta Univerzity Karlovy

martina.vokacova@ff.cuni.cz

Mgr. Jakub Jehlička

Filozofická fakulta Univerzity Karlovy

jakub.jehlicka@ff.cuni.cz

Mgr. Jan Bičovský, Ph.D. Filozofická fakulta Univerzity Karlovy

jan.bicovsky@ff.cuni.cz

Mgr. Eva Lehečková, Ph.D. Filozofická fakulta Univerzity Karlovy

eva.leheckova@ff.cuni.cz
Jazyková diverzita představuje jedno z témat současné lingvistiky, které má nepopiratelný společenský přesah. Podle UNESCO je jazyková diverzita součástí kulturní diverzity. V České republice se kulturní diverzita reflektuje i $\mathrm{v}$ rámcových vzdělávacích programech ${ }^{2} \mathrm{v}$ průřezovém tématu multikulturní výchova. Reálně se však popularizaci jazykové diverzity $\mathrm{v}$ českém kontextu věnuje jen omezená pozornost. Jedním z př́hodných způsobů, jak lze přispět ke zvýšení všeobecného povědomí o tomto tématu, je prezentace formou interaktivní expozice zacílené na žáky základních a středních škol. Jako př́klad možné realizace tohoto cíle představujeme výstavu s únikovou hrou, která proběhla v rámci Evropského dne jazyků v Kampusu Hybernská v roce 2019 pod záštitou Filozofické fakulty Univerzity Karlovy a její popularizačně-vzdělávací platformy Library of Languages / Knihovna řečí.

\section{Jazyková diverzita z hlediska lingvistiky}

Všeobecný konsensus $\mathrm{v}$ lingvistice stanovuje současný počet světových jazyků mezi 6 a 7 tisíci jazyky mluvenými i znakovými (těch druhých je řádově několik set). Zároveň platí, že a) více než polovina všech jazyků má méně než 10 tisíc mluvčích (graf 1) a že b) přibližně třetina jazyků spadá do kategorie více či méně ohrožených (graf 2), tj. počet jejich mluvčích stabilně klesá ${ }^{3}$ Světová jazyková diverzita, podobně jako diverzita biologická, představuje křehký ekosystém podléhající negativním vlivům globalizace včetně klimatických změn. Teprve relativně nedávno si lingvisté začali plně uvědomovat, že se jazyky od sebe liší v mnohem větší míře, než se na základě vlivných teorií jazyka předpokládalo. Terénní výzkum zaměřený na dokumentaci jazyků totiž u mnoha tzv. absolutních (bezvýjimečně platných) univerzálií doložil takové varianty vyjádření, které podle předpokladů o univerzáliích neměly existovat. Takové protiprríklady byly nalezeny už na základě dosud popsaných cca $8 \%$ z doložených jazyků, pravděpodobnost objevení dalších výjimek z univerzálních pravidel je tedy při nárůstu popsaných jazyků vysoká. Ukazuje se tak, že pokud existuje nějaký základní distinktivní rys jazyka jakožto komunikačního systému, je to jeho 
inherentní variabilita (Evans a Levinson, 2009). Ačkoli v současnosti věnují lingvisté popisu a dokumentaci jazyků mnohem větší úsilí než kdykoli v minulosti, je jisté, že velké množství jazyků zanikne, aniž bychom o nich měli dostatečné informace (např́klad aniž by existoval jejich základní slovník, gramatika nebo nahrávky projevů různých mluvčích). Zánik jazykové diverzity je současně zánikem diverzity kulturní - spolu s jazykem mizí sociální normy, vzorce chování a způsoby konceptualizace světa specifické pro dané jazykové společenství. Dlouhodobější predikce se různí, ale i konzervativní odhady předpokládají, že do konce tohoto století zaniknou dvě třetiny soudobých jazyků. Péče o jazykovou diverzitu spadá mj. do gesce UNESCO, které spravuje jeden z referenčních zdrojů o ohrožených jazycích - The World's Atlas of Languages in Danger ${ }^{4}$ (dřive The Red Book of Endangered Languages). V Evropě ochrana jazykové diverzity náleží do kompetence Rady Evropy, díky níž byla přijata Evropská charta regionálních či menšinových jazykủ zavazující členské státy $\mathrm{k}$ ochraně a péči o regionální a neteritoriální jazyky (v ČR ratifikováno $\mathrm{v}$ roce 2007).

Lingvistické výzkumy jazykové diverzity jsou spojené především se třemi Instituty Maxe Plancka: v Lipsku, Jeně a Nijmegenu. Pod vedením nijmegenského institutu byl v letech 2000 2011 realizován rozsáhlý projekt DOBES (Dokumentation bedrohter Sprachen), v jehož rámci bylo zdokumentováno bezmála 70 dosud nepopsaných ohrožených jazyků po celém světě. Instituty v Lipsku a v Jeně stojí za online databázemi jazyků světa - World Atlas of Linguistic Structures ${ }^{5}$, který ukazuje jazykové rysy popsaných jazyků světa, a The Glottolog ${ }^{6}$, což je nejrozsáhlejší jazyková databáze (přes 8000 hesel včetně zaniklých jazyků) obsahující bibliografické reference, geografické údaje a informace o genetické klasifikaci a stupni ohrožení jazyka. Př́mo na ohrožené jazyky je zaměřena databáze Endangered Languages Project ${ }^{7} \mathrm{v}$ rámci společného projektu First Peoples' Cultural Council a University of Hawai'i at Mānoa, která
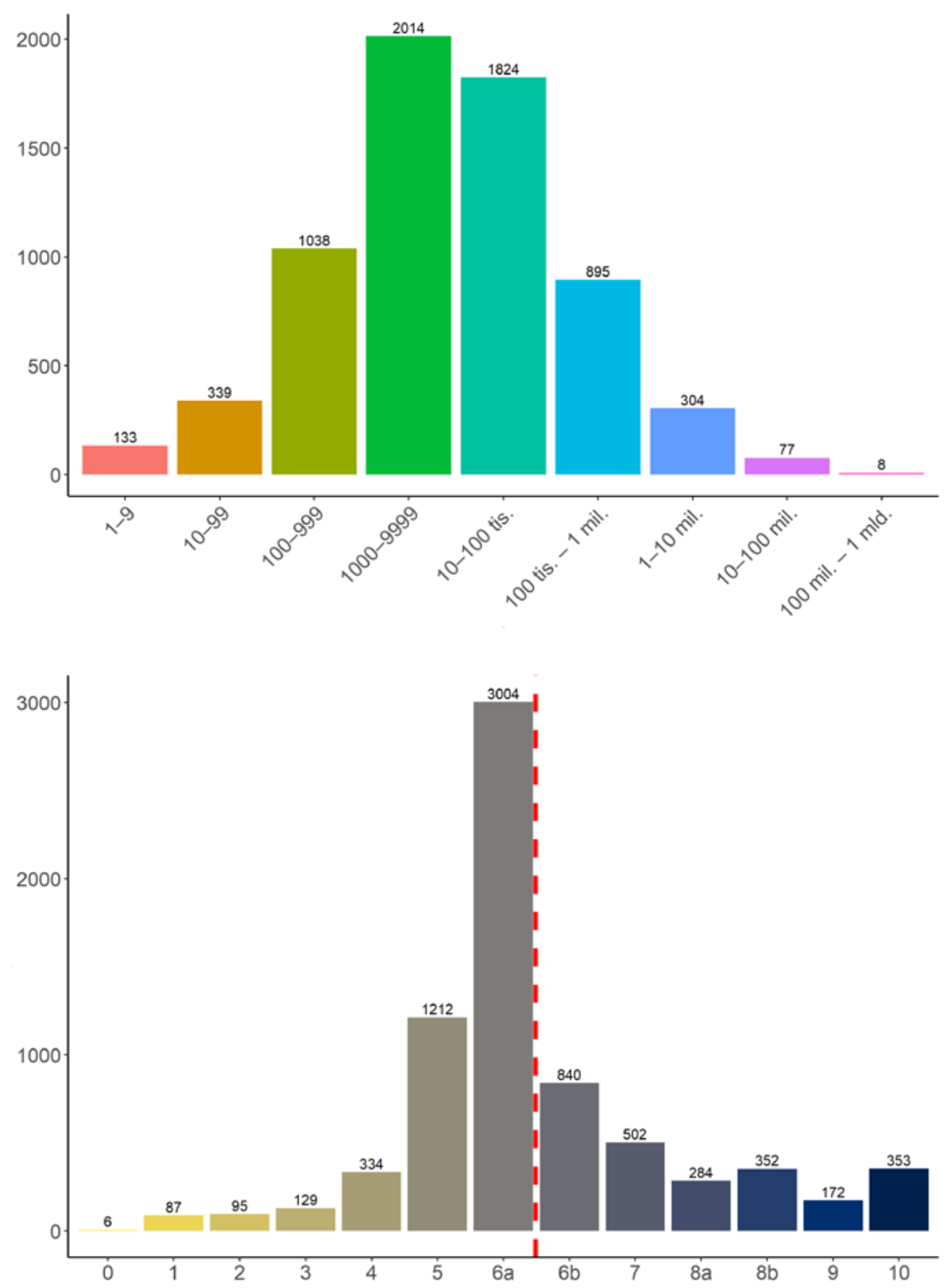

zahrnuje přes 3000 jazyků z celého světa (včetně jednoho záznamu z ČR - českého znakového jazyka, který je zde zahrnut v kategorii „zranitelné“). Pro referenční účely je lingvisty hojně využívána i podrobná databáze jazyků světa Ethnologue $e^{8}$ spravovaná křestanskou organizací SIL International.

Z české perspektivy je dobře známým prŕkladem ohroženého jazyka a dokumentačních aktivit s tím spjatých lužická srbština. Menší povědomí existuje o ohrožených jazycích prímo na našem území, mezi něž patří např. severocentrální romština nebo český znakový jazyk.

\section{Jazyková diverzita jako předmět zážitkové expozice}

$\mathrm{V}$ jednom z předchozích čísel časopisu Muzeum se Michal Stehlík (2018) zamýšlí
Graf 1: Distribuce jazyků světa podle počtu mluvčích (data: Ethnologue)

Graf 2: Distribuce jazyků světa podle stupně ohrožení EGIDS (Lewis a Simons 2010 $0=$ international, $10=e x-$ tinct), stupně $6 b-9$ (napravo od přerušované čáry) označují ohrožené jazyky (data: Ethnologue)

4 http://www.unesco.org/ languages-atlas/ 5 https://wals.infol 6 https://glottolog.org/ 7 http://endangeredlanguages. coml

8 https://www.ethnologue.com/ 


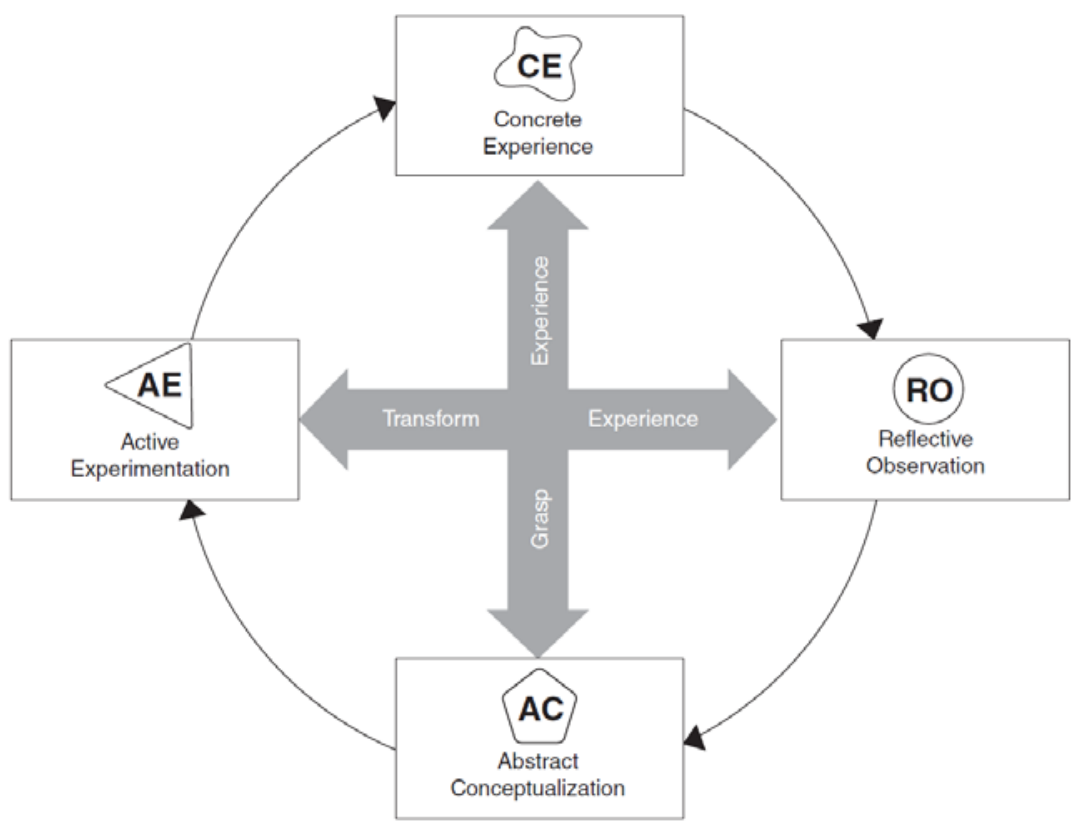

Obr. 1: Cyklus záźitkového učení uváděný Davidem Kolbem $(2015$, s. 51) předpokládá čtyři fáze, ve kterých 1) něco zažíváme, 2) to, co zažíváme, reflektujeme, 3) na základě reflexe zážitek konceptualizujeme a 4) nakonec pretváríme ve zkušenost nad rolí muzeí v ",tekuté“ době, v níž muzea, podobně jako jiné vzdělávací instituce, pozbyla monopolu na předkládané informace. Řešením ztráty této exkluzivity má být „sázka na formu“, přičemž ona forma má být na jednu stranu „skutečně nová", na druhou stranu "navázaná na promyšlený směr dané instituce" (s. 38). Přetrvávající konkurenční výhodou muzeí zatím ale zůstává autenticita výstavních objektů.

Jako zprávu o stavu řešení zmiňované ztráty exkluzivity v českých muzeích můžeme číst studii Niny Wančové (2018) v tomtéž periodiku. Autorka provádí kvantitativní šetření sledující tři hypotézy (s. 25):

(1) Jestliže proběhla v muzeu během posledních 10 let výraznější změna expozic, jsou moderní prezentační postupy užity ve velké míře;

(2) Aktivizační metody jsou již obvyklou součástí nabídky aktivit pro návštěvníky muzeí a většina muzeí je nabízí;

(3) Česká muzea nedostatečně využívají potenciál nových médií v komunikaci s veřejností.

Průzkum autorky provedený roku 2015 potvrdil hypotézu (2), hypotézy (1) a (3) vyvrátil. Moderní prezentační postupy tedy nejsou běžnou praxí českých expozic, aktivizační metody jsou součástí nabídky většiny muzeí v podobě doprovodných aktivit (nejčastěji přednášky/besedy, workshopy, pracovní listy) a komunikace $s$ veřejností prostřednictvím nových médií probíhá ve větší míře, než bylo předpokládáno.
Pro výstavu o jazykové diverzitě a ohrožených jazycích z toho vyplývá dvojí: Zaprvé se mnohem více než klasická muzejní výstava musí spolehnout na inovativnost způsobu, kterým předkládá informace, protože nedisponuje žádnými vlastními autentickými předměty; a zadruhé, pokud má být ona forma skutečně nová, je potřeba, aby participace návštěvníků nekončila u doprovodné aktivity, ale stala se integrální částí výstavy.

K dosažení těchto dvou cílů jsme při koncipování výstavy vycházeli jednak z teorie zážitkového učení (experiential learning theory), jednak z novějších trendů ve vzdělávání, které jsou s touto teorií kompatibilní nebo jsou někdy chápány přímo jako její podtyp, a to z učení založeného na hře (game-based learning) a z gamifikace (gamification). Teorie zážitkového učení předpokládá, že poznatky, které doprovází zážitek, jsou efektivnější, nebot' jsou snáze osvojitelné a aplikovatelné. Skrze zážitek a jeho reflexi dospíváme ke zkušenosti, na jejímž základě můžeme vyhodnocovat nové situace (Kolb 2015, viz obr. 1). Množina aktivit, které se tímto pojmem dají zastřešit, je poměrně široká, např́iklad z výše uvedených doprovodných aktivit, které se v nabídce muzeí objevují nejčastěji, by mohla zahrnovat workshopy a pracovní listy. K zprostředkování onoho zážitku se v současnosti stále častěji užívají herní principy, at už $\mathrm{v}$ podobě výše zmíněné gamifikace nebo game-based learning. Ohledně zacházení s pojmy gamifikace a game-based learning nepanuje v odborné literatuře shoda. Pojmem game-based learning (GBL) se většinou míní učení, při němž jsou využívány digitální hry (Plass et al. 2020), ačkoli existují i studie věnující se v rámci GBL hrám, které digitální nejsou (Abbott 2019; Wang a Zheng 2020). Gamifikace bývá většinou definována jako užití herních prvků mimo herní prostředí (Deterding et al. 2011) a v tomto významu stavěna do kontrastu právě s GBL na rozdíl od GBL se v př́ipadě gamifikace nejedná o kompletní hru, pouze o vybrané prvky a oproti GBL není během gamifikace vzdělávací aktivita uzpůsobována herním 
účelům (Plass et al. 2020, s. 4). Jako typický príklad výsledku gamifikace by byl v kontextu výstavy vnímán pracovní list, který by zvyšoval motivaci návštěvníků prohlédnout si další exponáty, typickým př́íkladem GBL by byla počítačová hra, jako je z českých vzdělávacích her např. Attentat 1942 od studia Charles Games". Vzhledem k tomu, že omezení pojmu GBL na digitální hry se nezdá být podložené studiemi, které by dokládaly, že proces učení podpořený digitální hrou má jiné charakteristiky či jinou úspěšnost než v př́ípadě hry nedigitální, chápeme GBL šířeji: jako učení založené na libovolné hře, která je kompletní - sleduje sice vzdělávací cíle, ale obstojí i samostatně, mimo kontext vzdělávání, bez režie vzdělávací instituce.

Gamifikací ve vzdělávání rozumíme aplikaci herních prvků na vzdělávací obsahy, přičemž míra gamifikace se může pohybovat na škále od pracovního listu až po kompletní hru (srov. např. definici uváděnou $\mathrm{v}$ kolektivní monografii Gamification in Learning and Education. Enjoy Learning Like Gaming (Kim et al. 2018, s. 27): "Gamification is to change something that is not a game through a game or its elements"). Všechny části níže prezentované výstavy o jazykové diverzitě a ohrožených jazycích lze tedy vnímat jako prríklady gamifikace a poslední z nich - únikovou hru Poslední mluvčí - rovněž jako př́íklad game-based learning ${ }^{10}$ (viz obr. 2 pro schematické zachycení našeho pojetí gamifikace).

$\mathrm{V}$ rámci tohoto trendu $\mathrm{v}$ zážitkovém učení (někdy se hovoří př́ímo o Gamebased Experiential Learning) roste i počet studií, které dokládají, že zážitkové učení založené na hře nebo herních prvcích zvyšuje jak motivaci k učení (např. Abbott 2019), tak jeho úspěšnost (posuzovanou výsledky vstupních a výstupních testů experimentální a kontrolní skupiny, např. Kaneko et al. 2018; Legaki et al. 2020). Na druhé straně existují i studie dokládající žádný nebo velmi malý vliv hry na úspěšnost osvojení poznatků (Veldkamp et al. 2020). To, vedle odlišností v herním designu, $\mathrm{v}$ typu vzdělávacího

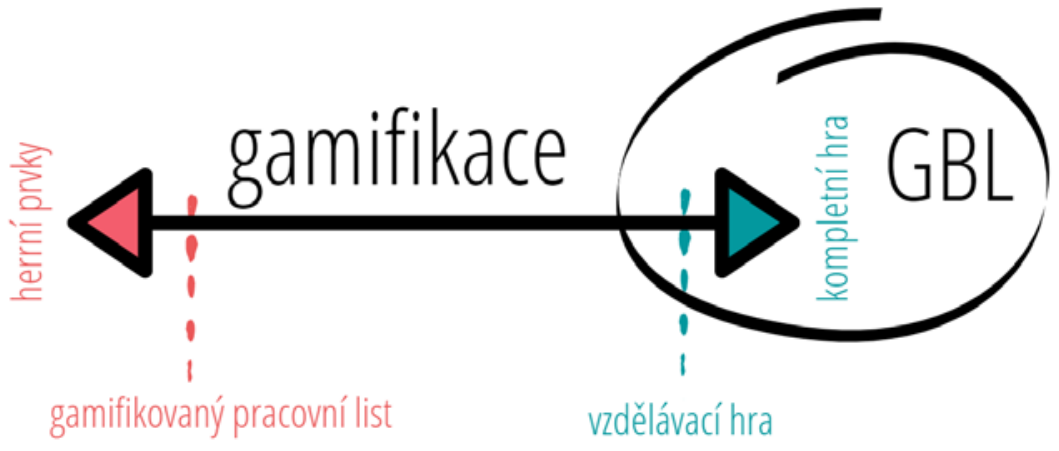

obsahu i v oblasti, do které se gamifikovaný obsah aplikuje, může být dáno také tím, že většina případových studií o využití her ve výuce se $\mathrm{k}$ teorii zážitkového učení vztahuje čistě intuitivně; aby tedy bylo možné game-based learning zařadit pod hlavičku zážitkového učení, měly by být při designu hry zohledněny všechny fáze zážitkového učení zmiňované výše - předkládaná hra by kromě zážitku měla nabízet i prostor pro jeho reflexi a přetvoření ve zkušenost.

Takto pojímaná gamifikace může být jedním z prostředků naplnění nově chápané role muzea jako prostoru sociální interakce a součásti (resp. spolutvůrce) komunity v duchu tzv. Nové muzeologie (Vergo, 1989; Simon, 2010), mezi jejíž pilíře náleží také zavádění participativních prvků. V „novém muzeu“ má být účastník skutečně účasten, vtažen do interakce nejen s vystavovanými obsahy, ale i do sociální sítě s ostatními participanty, vedle individuálních zážitků si má odnášet zážitky komunitní. Nina Simon nap̌r. představuje ve své vlivné publikaci The Participatory Museum (2010, s. 26) žádoucí vývoj zážitku návštěvníka v pěti postupných krocích, při kterých se s vyšší mírou participace mění i jeho perspektiva z individuální na kolektivní, z „já“,
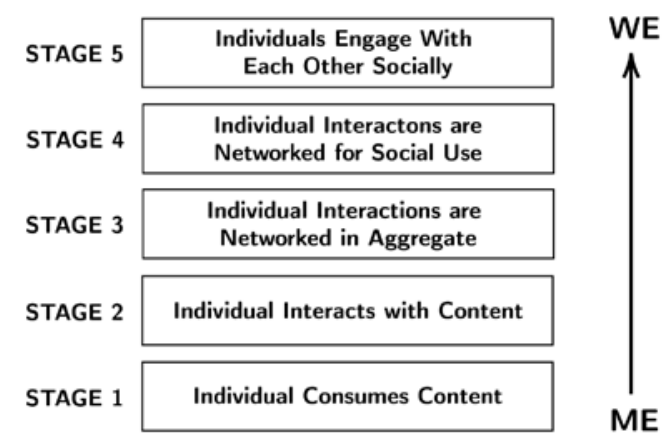

Obr. 3: Schéma vývoje zážitku návštěvníka podle Simon (2010)
Obr. 2: Škála gamifikace

9 https://store.steampowered.com/app/676630/ Attentat_1942/?|=czech 10 Tím se jedná o poměrně unikátní počin - ze systematického přehledu vzdělávacích únikových her, provedeného Veldkamp a kol. (2020), se dá soudit, že se ve většině príipadů jedná o príklady gamifikace, nikoli však už GBL. 
11 https://www.nationaalarchief.nl/beleven/onderwijs/ wie-ben-ik-wie-was-jij.

12 Pro téma obchod a otrokáŕství se tak vaším zrekonstruovaným diskusním partnerem může stát jak jeho "obět”, unesený chlapec Quaco, tak jeho "pachatel", reditel Nizozemské východoindické společnosti Roelof Blok. $V$ boji za rovnoprávnost můžete postupovat po boku Aletty Jacobs, první vysokoškolsky vzdělané Nizozemky, surinamského kritika kolonialismu Antona de Koma nebo LGBT+ ikony Anny Blaman. 13 Viz https://www. rijksmuseum.nl/nl/ ontdek-meesterwerken. 14 Viz https://diefenbunker. calen/. přijímajícího obsah, na "my", obsah dotvářející ve vzájemných interakcích.

Jako ukázka toho, jak je možné nechat všechny tyto kroky proběhnout po smysluplné a konzistentní cestě za pomoci gamifikace, může sloužit např́iklad výstava Wie ben ik, wie was jij? (Kdo jsem já, kdos byl ty?) v Nationaal archief Den Haag ${ }^{11}$. Výstava, zacílená na žáky vyšších ročníků základních a nižších ročníků středních škol, pomocí archivních pramenů představuje vybrané historické osobnosti reprezentující čtyři témata: obchod a otrokářství, migraci, dobro a zlo ve druhé světové válce a boj za rovnoprávnost. Expozice pracuje s konceptem imerzivního zážitku a historické osobnosti nechává komunikovat s návštěvníky pomocí chatu podobného aplikaci WhatsApp. Návštěvníci historickým postavám pomáhají s rozhodováním v důležitých životních situacích, čímž jsou nuceni se do nich sami vcítit. Zážitek je podpořen i tím, že na výstavě nikdo nemůže vidět všechno - školní třída je rozdělena do menších skupin výběrem jednoho $z$ výše uvedených témat a historické postavy ${ }^{12}$. Návštěvníci prostorem procházejí ve tmě: kudy se vydat, jim radí světelná signalizace umístěná v prostoru. Ta je vždy na základě interakce s tabletem zavede k dalšímu archivnímu dokumentu či objektu spojenému s jejich postavou. Návštěvník pak nově zpřístupněné objekty prozkoumává kapesní svítilnou a pátrá v nich po odpovědích na otázky položené jeho digitálně oživlým historickým průvodcem. Leitmotivem výstavy je zamyšlení nad tím, jakým zpo̊sobem jsou možnosti, které máme k řešení určitého dilematu k dispozici, omezeny místem, časem nebo prostředím, do kterého se narodíme. Ke zvýšení motivace se tato v zásadě detektivní hra hraje na čas, po vypátrání minulosti jedné konkrétní postavy následuje diskuse s ostatními účastníky o tom, co se svým průvodcem zažili a jak by se v určitých situacích rozhodovali oni. Poslední částí zážitku je prohlídka skutečného archivu s opravdovým průvodcem, který třídě vysvětlí, k čemu archivy a archiválie slouží
(Overmeer 2019). Dotváří se tím komplexní dojem z archivu jako paradoxně poměrně živého místa setkávání různých lidí v různém čase. Výstava získala v roce 2020 nizozemské ocenění Museumeducatie Prijs jakožto druhý nejlepší počin v oblasti muzejní edukace. Úspěchu dosáhla vhodně provedenou gamifikací archivních pramenů, neopomíjející navíc poskytnutí dostatečného prostoru pro dotvoření zážitku a jeho reflexi.

Z dalších projektů, které gamifikaci zdařile využívají a mohly by ostatním vzdělávacím institucím sloužit za příklad, lze jmenovat nap̌r. aktuální virtuální prohlídku Rijksmusea Amsterdam ${ }^{13}$, "největší únikovku světa" v ottawském Diefenbunker Canada's Cold War Museum ${ }^{14}$ nebo třeba Zkus Kuks ${ }^{15}$. Přesto je v oblasti muzejnictví termín gamifikace často přijímán s určitou rezervovaností. Jednou z pravděpodobných př́íčn tohoto postoje je původ gamifikace v oblasti marketingu, jeho propojení s cílem zvýšení zisku a citlivou otázkou sběru osobních údajů. Literární vědec a herní designér Ian Bogost se k tomuto aspektu vyjadřuje ve svém příspěvku Why Gamification Is Bullshit (2014) ve sborníku The Gameful World. Approaches, Issues, Applications. Gamifikaci vnímá právě především jako nekalou a lacinou praktiku zneužívající své uživatele. K nelichotivému obrazu gamifikace přispívá i její běžná, výše uvedená definice - užití herních prvků mimo herní prostředí. Př́źnačná pro tuto definici, potažmo pro zacházení s gamifikací, je absence účelu, s jakým jsou herní prvky do neherního světa aplikovány. Gamifikace, zejména jako marketingový nástroj, je ve většině případů redukována pouze na jednoduchý systém sbírání bodů a získávání odměn (tzv. reward-based gamification). Scott Nicholson $(2012,2015)$ proto raději mluví specificky o „smysluplné gamifikaci" (meaningful gamification) a k běžné definici přidává dovětek o tom, k čemu má sloužit: „Meaningful gamification is the use of game design elements to help users find meaning in a nongame context" (2012, s. 1, zvýraznili autoři). Domníváme se, že Nicholsonova cesta je nosným 
přístupem, který umožňuje odlišovat jednoduché herní mechanismy za účelem zisku od kreativních způsobů pronikání $\mathrm{k}$ obsahům, $\mathrm{v}$ případě edukativních výstav za účelem zážitkového učení. Tohoto pojetí se držíme i v následujícím příkladu výstavy o jazykové diverzitě.

\section{Výstava o jazykové diverzitě}

Jak vyplývá z předcházejícího oddílu, v rámci revize tradiční role muzea sílí důraz na aktivní roli samotné instituce a její angažovanost a odpovědnost vưči komunitě - viz např. navrženou aktualizaci definice muzea Mezinárodní rady muzeí (ICOM), jež popisuje muzeum jako místo, kde se „uznávají [acknowledge] a řeší konflikty a výzvy současnosti“" ${ }^{\prime 16}$. Zánik jazykové diverzity bezesporu patří mezi závažné výzvy současnosti, o nichž zároveň existuje relativně omezené povědomí. Interaktivní výstava, již představujeme $\mathrm{v}$ tomto př́spěvku, byla součástí programu festivalu Evropský den jazyků v Kampusu Hybernská, pořádaného vzdělávací platformou Library of Languages / Knihovna řčč $\iota^{17} \mathrm{FF}$ UK v rámci Evropského dne jazyků v roce $2019^{18}$. Evropský den jazyků se slaví každoročně 26. zárí z iniciativy Rady Evropy na podporu jazykové diverzity v Evropě ${ }^{19}$. Na výstavě se autorsky podíleli autoři tohoto textu a Veronika Pleskotová (Library of Languages, Národní muzeum), dále pak Filip Kazda (kurátor Galerie HYB4 v Kampusu Hybernská) a Jan Maryško (Quest Café, kavárna s únikovými hrami). Zastřešujícím tématem festivalu byla jazyková diverzita, se zvláštním zrretelem k ohroženým jazykům. Koncepce výstavy vycházela z paralely mezi jazykovou diverzitou a biodiverzitou, s oporou o článek 1 Všeobecné deklarace o kulturní diverzitě $\mathrm{UNESCO}^{20}$, podle níž je kulturní a jazyková diverzita pro „lidský rod stejně nutná, jako je biodiversita nezbytná pro řád živého světa". S touto paralelou se běžně pracuje nejen $\mathrm{v}$ lingvistice (SkutnabbKangas a Harmon 2017; Harmon a Loh 2018), ale také (a především) na úrovni kulturních institucí, jako je UNESCO. Skutnabb-Kangas a Harmon uvádějí řadu spojitostí mezi jazykovou diverzitou a biodiverzitou:

„Obě jsou ve své podstatě evoluční, jelikož jak živé druhy, tak i jazyky jsou výsledkem vývoje ze společného genetického nebo jazykového předchůdce. Dějiny druhů a jazyků je možné sledovat pomocí podobných taxonomických metod, kterých výsledkem je vytvoření podobných fylogenetických stromů, které ilustrují proces evolučního větvení. Oba druhy rozmanitosti lze hierarchicky klasifikovat, přičemž geny / druhy / ekosystémové žebřičky biodiverzity se shodují se strukturálními / jazykovými / rodovými úrovněmi jazykové rozmanitosti. (...) A konečně (...) zánik biologické a jazykové rozmanitosti sdílí stejnou základní příčinu: neoliberální globalizace ${ }^{\star 21}$.

S paralelou mezi jazykovou a př́rodní diverzitou je spojený metaforický rámec ohrožení, přičemž jako příčina ohrožení se chápe lidská činnost (nikoli přirozené procesy). Součástí tohoto rámce je tedy nutně $\mathrm{i}$ apel $\mathrm{k}$ aktivitě na straně recipienta, tedy k záchraně.

Naléhavost plynoucí z uvedeného metaforického rámce byla akcentována již ve vizuálu Evropského dne jazyků, a to

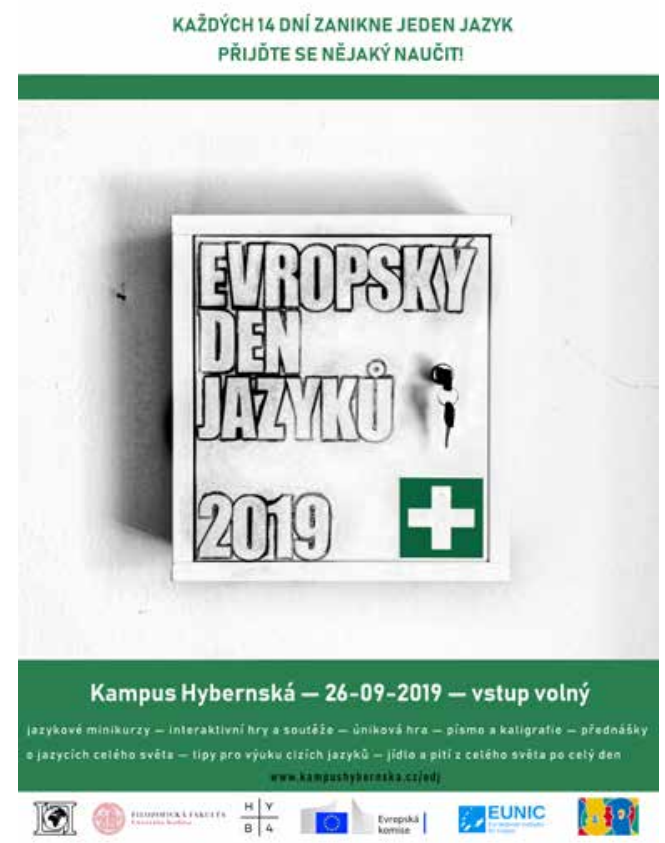

Obr. 4: Plakát k Evropskému dni jazyků v Kampusu Hybernská 2019
16 http://icom-czech.mini.icom. museum/icom/definice-muzeal 17 https://libraryoflanguages. ff.cuni.czl

18 První ročník se odehrál $v$ roce 2018, v roce 2020 se vzhledem $k$ nouzovému stavu festival nekonal.

19 https://edl.ecml.at/ 20 http://www.unesco.org/ new/fileadmin/MULTIMEDIA/ HQ/CLT/diversity/pdf/declaration_cultural_diversity_cs.pdf $\mathbf{2 1}$ "Both are fundamentally evolutionary, with all living species and languages the result of descent with modification from, respectively, a common genetic or linguistic ancestor. The histories of species and languages are traced by similar taxonomic methods and result in similar phylogenetic trees that reflect an evolutionary branching process. Both kinds of diversity can be classified hierarchically, with the genes/species/ecosystem ladder of biodiversity matched by structural/language/lineage levels of linguistic diversity. (...) Finally (...) the extinction of biological and linguistic diversity shares the same root cause: neoliberal globalization." (Skutnabb-Kangas a Harmon 2017). Překlad: M. Smidová. 


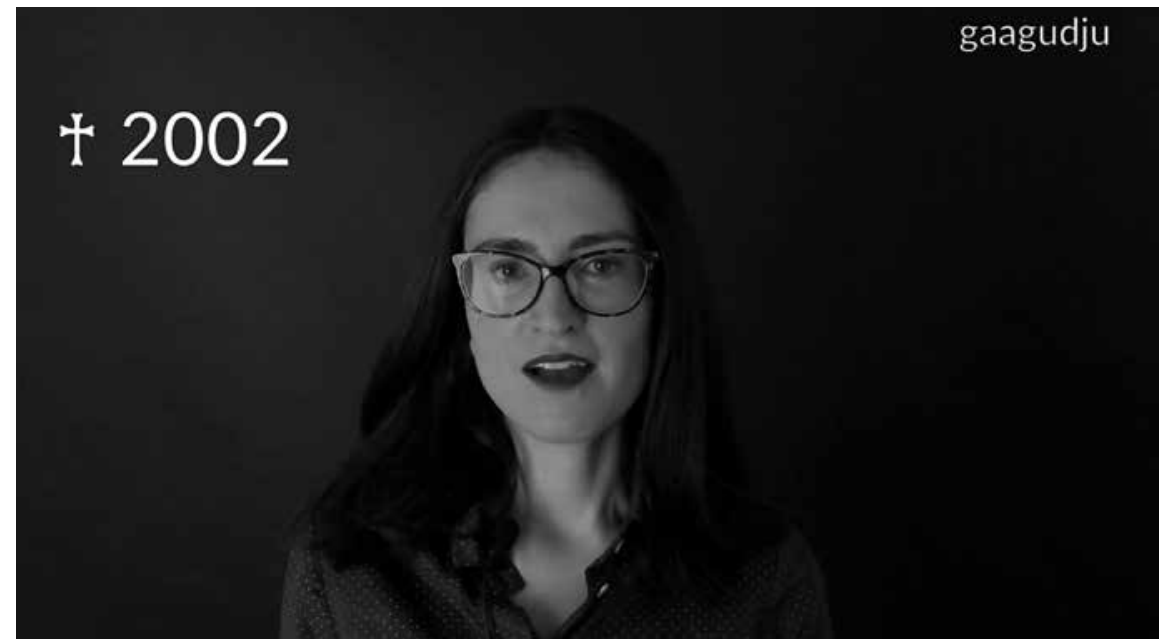

Obr. 5: Ukázka z propagačního videospotu $k$ Evropskému dni jazyků v Kampusu Hybernská 2019

22 https://www.youtube.com/ watch? $v=H 4 J \mathrm{~J} 2 W M 7 B o o$

23 Zvuková výstava je volně dostupná zde: http://www. kampushybernska.cz/edj/ vystavy/mrtve-jazykyl ústředním motivem monochromatické lékárničky s výrazným zeleným křížem a prímočarým mottem „Každých 14 dní zanikne jeden jazyk - přijd'te se nějaký naučit" (obr. 4). K propagaci akce byl rovněž využit videospot ${ }^{22}$, v němž se v rostoucím tempu střídali mluvčí pronášející názvy vybraných mluvených i znakových jazyků zaniklých za posledních 50 let s uvedením roku zániku (obr. 5).

Samotnou expozici tvořil soubor výstavních prvků rozmístěných v Galerii HYB4 Kampusu Hybernská a v dalších částech areálu. Obecný organizační princip expozice byl postaven na personifikaci jejího leitmotivu - zániku jazyka - skrze koncept posledního mluvč́́ho. Jakkoli je z hlediska jazykové dokumentace koncept posledního mluvčího problematický (srov. Evans 2001), pro autory expozice posloužil jako vhodný klíč $\mathrm{k}$ tématu jazykové diverzity právě kvůli důrazu na její lidský rozměr - zcela v duchu antropocentrických východisek našeho vnímání světa a získávání zkušeností s ním (srov. např. Lakoff a Johnson 1980). Jednotlivé části expozice využívaly motivu posledního mluvčího různým způsobem, s různou mírou interaktivity a s různou afordancí (Gibson 1979) k aktivní participaci recipienta (Allen a Gutwill 2004; Achiam et al. 2014). Expozicí bylo možné procházet libovolně, jejím přirozeným začátkem však byla část umístěná v prostoru Galerie HYB4 pod názvem Biosféra jazyků.

\subsection{Biosféra jazyků - expozice $v$ Galerii HYB4}

Instalace $\mathrm{v}$ první z pěti místností galerie byla koncipována jako uvedení do pojmu jazyková diverzita. Na textových panelech velkého formátu byly prezentovány základní informace o počtu a distribuci jazyků světa, a to s důrazem na 1) fakt, že typický jazyk má relativně malý počet mluvčích a 2) že významná část jazyků světa je více či méně ohrožena zánikem. Zároveň zde byla uvedena centrální paralela mezi zánikem biodiverzity a jazykové diverzity - jeden $z$ infopanelů byl věnován stupnicím ohroženosti živočišných druhů a jazyků (např. stupnice IUCN a na ni odkazující stupnice UNESCO). Tuto část expozice lze $\mathrm{v}$ rámci celého souboru výstavních prvků označit za nejvíce statickou. Absence interaktivních prvků a důraz na informativnost zde sice staví návštěvníka do role pasivního recipienta, nicméně $\mathrm{v}$ poslední části expozice, interaktivní hře Zachraň ohrožený jazyk!, dojde k její reinterpretaci (viz níže).

V navazující místnosti galerie byla umístěna část expozice nazvaná Poslední mluvčí tvořená infopanely a audiovizuální projekcí. V této části expozice již dochází k posunu od objektivizující informativnosti k oslovení návštěvníka prostřednictvím subjektivní perspektivy - zaměřením na mluvčí jako lidské bytosti a jejich príběhy. Posun je signalizován rámujícím panelem s překladem básně Můj jazyk od evenkského básníka A. Němtuškina, která často doprovází materiály UNESCO věnované ohroženým jazykům. Textové panely doplňovala audiovizuální projekce tvořená smyčkou ze segmentů dokumentárních filmů o posledních mluvčích různých jazyků (např. livonštiny nebo mandanštiny, ale také o mluvčích jazyků revitalizovaných, jako je kornština). Samotné panely obsahovaly informace o posledních mluvčích vybraných tak, aby reprezentovali jazyky z různých částí světa.

Následující část expozice tvořila zvuková instalace s názvem Hlasy mrtvých jazyků $\mathrm{v}$ podobě nahrávek segmentů literárních textů v 16 mrtvých jazycích (např. akkadštině, staré čínštině, védštině nebo staroslověnštině) čtených $\mathrm{v}$ rekonstruované zvukové podobě ${ }^{23}$. Na nahrávkách, které byly poř́zzeny ve zvukovém studiu Mr. Wombat v Kampusu Hybernská, vystupují přední odborníci na dané jazyky, 

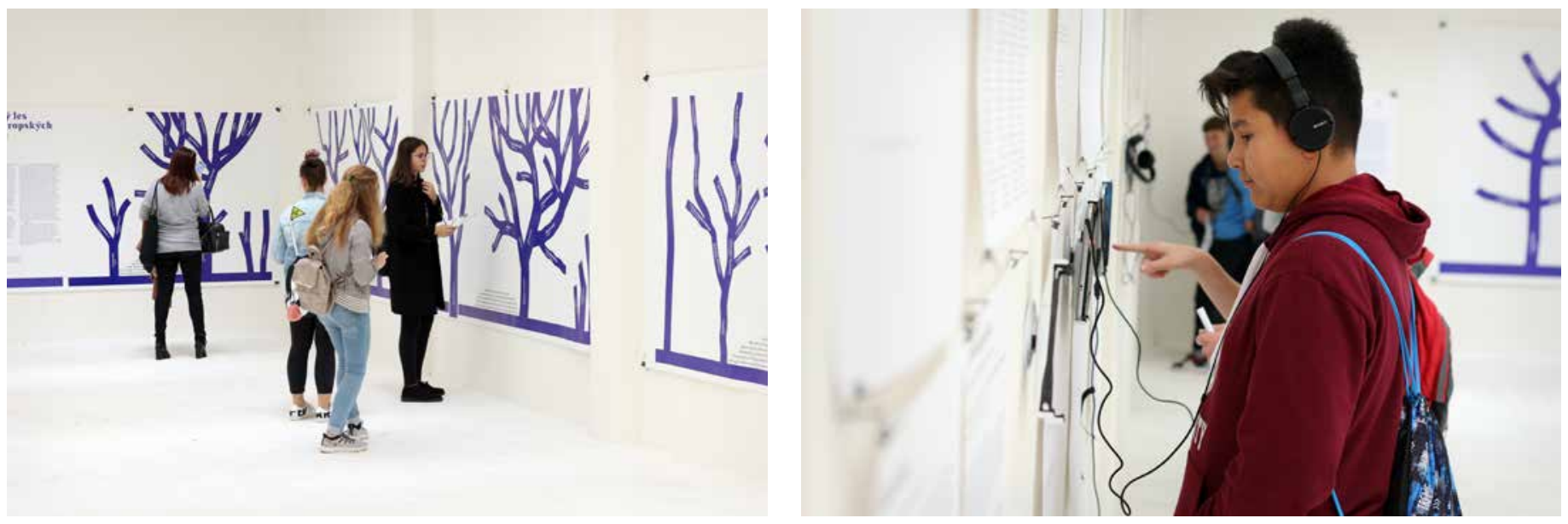

většinou z Filozofické fakulty UK, ale také hosté ze zahraničních univerzit. Nahrávky doprovázely panely s transkripcí textů, informací o jazyce a konkrétním díle a s překladem do češtiny. U tématu mrtvých jazyků, fosilizovaných v literárních památkách, hrozí, že nebude pro cílovou skupinu žáků ZŠ a SŠ př́liš atraktivní. $V$ prrípadě této instalace se potenciál $\mathrm{k}$ oslovení návštěvníků zvyšuje jednak interaktivností (ovládáním pomocí zabudovaných dotykových zařízení se sluchátky), jednak výběrem ukázek: úryvky bud' byly obsahem pozoruhodné (latinská kletba), nebo byly žákům povědomé díky novočeské podobě (např. křestanská modlitba Otčenáš ve staroslověnštině, ukázky Béowulfa či Písně o Nibelunzích). Z obecné perspektivy měla tato část výstavy podnítit zájem návštěvníků o roli vývoje jazyka a možnosti jeho rekonstrukce v kontextu dokumentace a záchrany ohrožených jazyků. Například v př́ípadě keltské kornštiny se právě rekonstrukční metody historické lingvistiky uplatňují při oživování jazyka na základě dostupných textů a doplňování chybějících jazykových prostředků, mimo jiné srovnáváním s př́ibuznou velštinou. Konečně také skutečnost, že zejména jazykům bez historické kontinuity do př́tomnosti, jako je akkadština či chetitština, lze v současnosti porozumět, je výsledek lingvistické rekonstrukce. Zároveň odborná pozornost věnovaná těmto jazykům $\mathrm{v}$ omezeném smyslu (v rámci komunity badatelů) vede i k jistému obnovení alespoň pasivní kompetence mluvčích daných jazyků.

V téže místnosti galerie byla dále umístěna instalace, která svým názvem opět evokovala zastřešující rámec jazykové biosféry: Les jazyků. Velkoplošný panel zachycoval klasifikaci evropských jazyků vizualizovanou jako les stromových struktur reprezentujících vývoj jednotlivých větví indoevropské jazykové rodiny a dalších rodin evropských jazyků (ugrofinská, semitská). Na jedné straně šlo sice o klasickou "statickou“ grafickou instalaci, od běžného zobrazování př́buznosti jazyků pomocí stromového grafu (obdoby geneaologického stromu) se ale zásadně lišila v několika ohledech. Jednak vlastním formátem instalace s půlkruhovým uspořádáním panelu, který tvořil pásmo pokrývající výstavní místnost, bylo docíleno jistého prostorového efektu umožňujícího kinestetický prožitek (Pashler et al. 2008) procházky lesem jakožto explicitní reprezentace ohromné šíře jazykové diverzity (a to pouze $\mathrm{v}$ (indo)evropském prostoru). Zároveň však byla tato instalace doplněna o zvukovou nahrávku vývoje slova bratr $\mathrm{v}$ indoevropských jazycích (z praindoevropského kořene $\mathrm{k}$ současným kognátům např́č jazyky). Nahrávka ilustrovala zřetelnou kontinuitu jazykového vývoje, tedy fakt, že to, co může působit na první pohled jako babylónské zmatení řečí, v sobě skrývá systematické rodové podobnosti, a to i tam, kde by to laik nemusel očekávat (srov. romské phral nebo irské bráthair). Nejen tedy synchronní diverzita jazyků, ale také její původ v procesech obdobných biologickému vývoji zde nacházejí unikátní zobrazení, jež umožňuje zrakem i poslechem zároveň vnímat dynamiku i rozsah diverzity.

Poslední instalace v prostorách Galerie HYB4 nesla název Zachran̆ ohrožený jazyk! Jednalo se o gamifikovanou instalaci (mechanickou, tj. bez elektronických prvků). Na instalaci byla navázána eponymní hra na bázi řešení hádanky. Instalaci tvořilo 15 uzamčených lékárniček, které vizuálně vycházely $\mathrm{z}$ hlavního motivu akce:
Obr. 6:24 Les jazyků

Obr. 7: Hlasy mrtvých jazyků
24 Vlastníkem práv $k$ obrazovým materiálùm č. 6 až 9 je Jan Henyš 

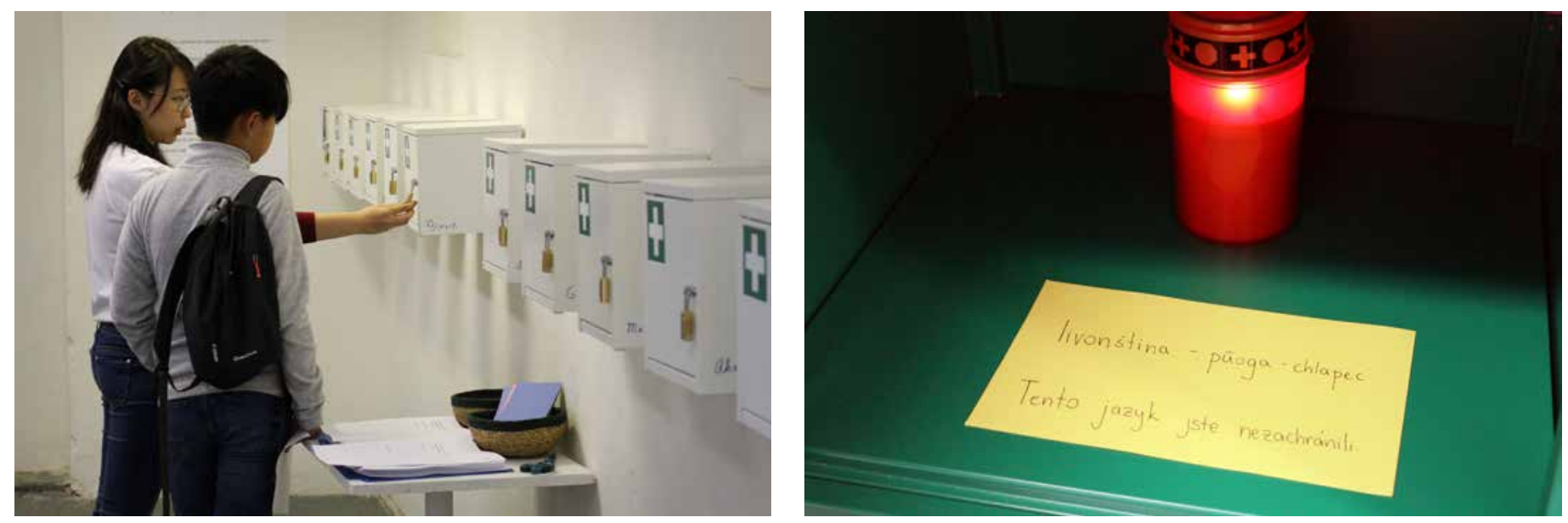

Obr. 8 a 9: Zachraň ohrožený jazyk!
3 zelené a 12 bílých lékárniček představujících různé ohrožené nebo již zaniklé jazyky. V zelených lékárničkách, které mohli návštěvníci jednoduše otevřít, "hořela" pietní elektrická svíčka za konkrétní zaniklý jazyk, který už není možné zachránit. Bílé lékárničky naopak nabízely návštěvníkům možnost aktivně se do záchrany jazyka zapojit. Tyto lékárničky byly uzamčené číselným zámkem, kódy $\mathrm{k}$ jejich odemčení bylo možné zjistit $\mathrm{z}$ infopanelů $\mathrm{v}$ předcházejících částech výstavy. V uzavřené lékárničce se skrýval úkol vyzývající návštěvníky $\mathrm{k}$ prrímé akci.

Účastníci hry tak získali nejen faktické informace o ohrožení a zániku jazyků, ale vlastním procházením hrou na otevírání schránek prodělali zkušenost, že jazyky zanikají, a zároveň si uvědomili možnosti, jimiž mohou sami $\mathrm{k}$ většímu povědomí o tomto tématu přispět.

$\mathrm{K}$ výstavě a Evropskému dni jazyků 2019 byla vydána upomínková série pohlednic propojujících vyhynulé/ ohrožené živočišné druhy se zaniklými/ ohroženými jazyky, která umožňuje přenést téma jazykové diverzity i mimo vlastní účastníky expozice, viz obr. 10. Jádro výstavy je putovní a je možné je nabídnout vzdělávacím a kulturním institucím včetně škol k vystavení. Např́klad část této expozice, Hlasy mrtoých jazykü, byla u př́ležitosti Evropského dne jazyků 2019 vystavena ve Vědecké knihovně v Olomouci.

\section{2 Úniková místnost}

Poslední částí výstavy, v níž se návštěvníci do záchrany jazyka mohli zapojit nejaktivněji, byla úniková hra, nazvaná stejně jako jedna z částí expozice Poslední mluvčí. $\mathrm{V}$ tomto případě se ovšem jednalo o jednu konkrétní, byt’ smyšlenou mluvčí jazyka sanskrtprstskrzkrk. Sanskrtprstskrzkrkština byla v rámci herního narativu vzácný, nedávno objevený jazyk, od jehož zdokumentování si lingvisté slibují stěžejní průlom v porozumění tomu, jak fungují jazyky světa. Poslední mluvčí však utrpí nehodu krátce před tím, než má práce na dokumentaci jazyka začít, a dojde u ní k poškození řečových center, které jí způsobí afázii - ztrátu řeči. Návštěvníci této části expozice museli být z kapacitních důvodů předem registrováni, z programu tedy věděli, že se budou účastnit únikové hry. Z toho důvodu už nebylo skutečnost, že se jedná o hru, potřeba nijak tematizovat. Jakmile návštěvníci vstoupili do předsálí, byli uvedeni do role tím, že je moderátoři uvítali jako dlouho očekávané participanty riskantního lingvistického experimentu - vstupu do mozku poslední mluvčí, v němž možná ještě půjde jazyk rekonstruovat. „Mozek poslední mluvčí" sestával ze tří místností - dvou viditelných a jedné tajné - a každá byla vystavěna kolem pochopení vybraného jazykového principu. Jednalo se o takové lingvistické principy, které ovlivňují naši konceptualizaci světa

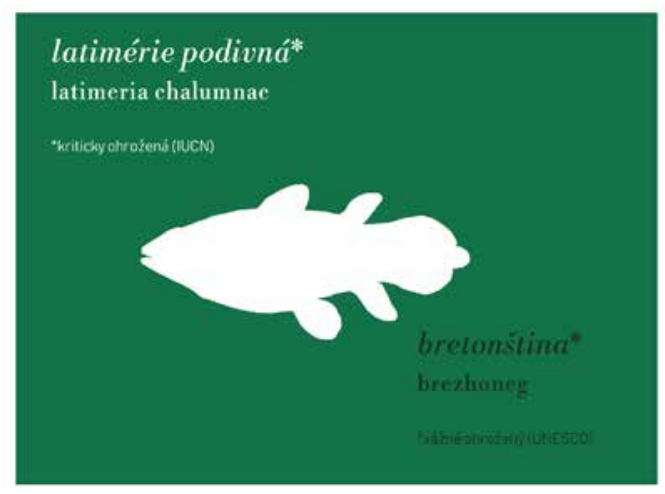

Obr. 10: Upomínková pohlednice k Evropskému dni jazyků 2019 


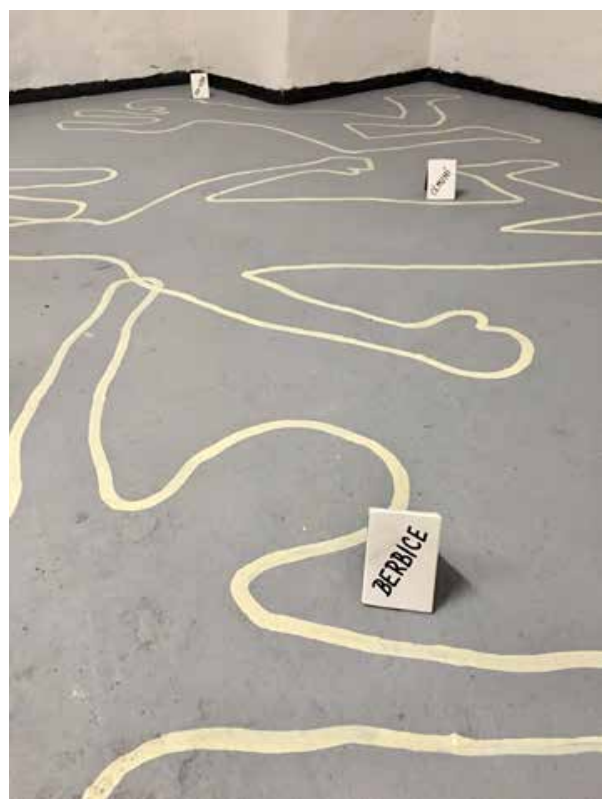

a u kterých se dá předpokládat, že pro rodilé mluvčí češtiny nebude triviální úkol si uvědomit, že se nejedná o principy univerzální. K „vyřešeni“" každé místnosti bylo potřeba daný princip identifikovat a pochopit, $\mathrm{k}$ čemuž vždy vedla série dílčích úkolů pracujících s lingvistickými reáliemi. Postup tak byl závislý na aplikaci lingvistických znalostí, které účastníci hry v jejím průběhu získávali. První místnost např́íklad byla založena na porozumění odlišnému systému počítání, které není založeno na desítkové soustavě, ale místo čísel počítá pomocí přibližně dvaceti různých částí těla (body part counting system), jako je tomu např. v jazyce kobon a dalších papuánských jazycích (Comrie 2013). Kromě obsahu dílčích úloh byla indicií k pochopení odlišného systému počíání i jejich forma - jednalo se o různé typy jednoduchých matematických príkladů. $\mathrm{V}$ průhledu do zamčené skříně, obsahující stěžejní artefakty pro postup do druhé místnosti, bylo např́iklad možné zjistit, že klíčem $\mathrm{k}$ jejímu odemčení je číslo, které návštěvníci získají, pokud $\mathrm{k}$ celkovému počtu ohrožených jazyků přičtou počet mrtvých jazyků, které jsou s nimi př́tomny v místnosti. Daná čísla samozřejmě nebylo potřeba znát, ale zjistit - $\mathrm{k}$ tomu prvnímu vedl reálný výtisk Lidových novin obsahující rozhovor s Evou Lehečkovou o právě probíhajícím Evropském dni jazykư ${ }^{25}$, který zároveň umocňoval herní zážitek tím, že cíli hry - záchraně jazyka - dodával na autenticitě a relevanci, ke správnému počtu mrtvých jazyků vedl naopak fiktivní výtisk bulvární novinové př́lohy, která jednak poskytovala část

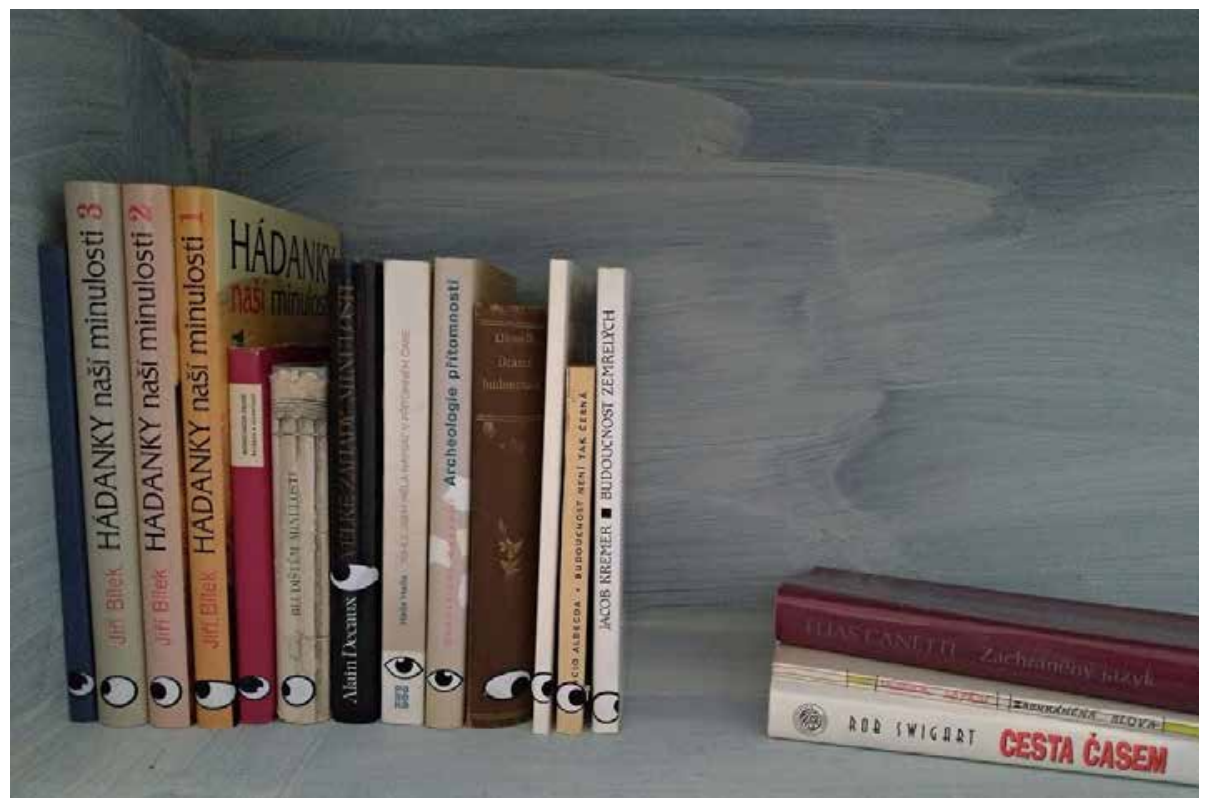

řešení dané úlohy, jednak dotvářela narativ hry tím, že ze záchrany jazyků činila mediálně sledované téma. Výčet mrtvých jazyků uvedených $\mathrm{v}$ této př́loze bylo pro vyřešení úlohy nutné ještě usouvztažnit s obrysy posledních mluvčích na podlaze, reprezentujících mrtvé jazyky (obr. 11). Každá úloha byla obsahem i formou přizpůsobena tématu dané místnosti a každá využívala k zprostředkování poznatků jiné médium - vedle zmíněných tištěných médií i média zvuková a dotyková.

Pokud se návštěvníci dostali až do poslední místnosti, uložené v mysli poslední mluvčí nejhlouběji, jejich úkolem bylo nahlédnout nesamozřejmost vlastní konceptualizace času, při které čas metaforicky pojímáme jako prostor, $v$ rámci nějž minulost leží za námi, zatímco budoucnost vidíme před sebou. Na konci úlohy založené na ajmarštině, jazyce, jehož mluvčí minulost a budoucnost vnímají v prostoru naopak - minulost, s ohledem na to, že už ji zažili, vidí před sebou, zatímco neznámá budoucnost leží za nimi (Núñez a Sweetser 2006), pak stačilo seřadit rozházené knihy do knihovny tak, aby ty pojednávající o minulosti byly vpředu a ty o budoucnosti vzadu (obr. 12), a hráči tím získali heslo do počítače obsahujícího poslední úlohu, která rozhodovala o tom, zda spolu se sanskrtprstskrzkrkštinou zachrání i její poslední mluvčí. Pokud se to nepovedlo v časovém limitu, nejednalo se o neúspěšnou misi: čím dále ve hře se návštěvníci dostali, tím větši část jazyka sanskrtprstskrzkrk se jim podařilo rekonstruovat a tím víc znalostí o jiných jazycích si osvojit. Jak ve hře, tak ve skutečnosti se jim tím
Obr. 11 a 12: Úniková hra Poslední mluvčí
25 Naše století prežije jen třetina jazyků. Rozhovor Petra Zídka s Evou Lehečkovou. Lidové noviny, príloha Orientace, 21. 9. 2019 
tedy určitým způsobem podařilo přispět k zachování jazykové diverzity. Úniková hra by měla být v roce 2021 v Kampusu Hybernská zpř́stupněna návštěvníkům pravidelně a bude na ni navázán lingvisticko-didaktický výzkum toho, jaké strategie vycházející ze znalosti jazyka účastníci únikové hry při řešení využivají.

\subsection{Možnosti evaluace}

V př́padě výstavy Biosféra jazyků kustodi $\mathrm{z}$ řad studentů Filozofické fakulty UK nejen pomáhali návštěvníkům výstavy v orientaci a udržovali v chodu interaktivní části výstavy, ale měli za úkol sledovat míru využití jednotlivých interaktivních prvků začleněných do expozice návštěvníky výstavy. Po skončení Evropského dne jazyků pak proběhla reflexe formou skupinového rozhovoru (focus group discussion). Potvrdil se tak např́klad náš předpoklad, že textové panely $\mathrm{v}$ první části výstavy nejprve žáci projdou relativně rychle, nicméně hra Zachraň ohrožený jazyk je k nim vrací a nutí je věnovat obsahu větší pozornost. V budoucnu bychom u vybraného vzorku návštěvníků rádi sledovali míru zapamatování informací ve čtyřech podmínkách: a) vystavení textové informaci, b) zapojení do interaktivní hry, c) kombinace textové informace a interaktivní hry, d) obohacení podmínky c) o navazující reflexi s cílem upevnění informace (např́klad online kvízem apod.). Pro všeobecný sběr zpětné vazby využijeme dotykové displeje u východu z výstavy, na nichž se zobrazí tři věty, každá $\mathrm{v}$ jiném jazyce $\mathrm{s}$ českým překladem, z nichž jedna bude vyjadřovat pozitivní hodnocení výstavy, druhá neutrální a třetí negativní. Návštěvníci si vyberou a po odhlasování se jim za odměnu a na rozloučenou na displeji zobrazí zajímavost o nějakém světovém jazyce, která nebyla součástí výstavy.

Jelikož se $\mathrm{v}$ př́padě únikové hry jednalo o pilotní provoz, nebyla získávána systematičtější zpětná vazba. S každou skupinou byl nicméně po skončení hry veden rozhovor nad úkoly, které plnily, a nad poznatky o jazycích, které $\mathrm{z}$ nich vyplývaly. Kromě toho byl jejich postup ve hře celou dobu pozorován prostřednictvím kamer, a to jak moderátory, tak $\mathrm{v}$ př́padě zájmu též pedagogickým doprovodem, jednalo-li se o školní skupiny. Získali jsme tak poměrně dobrou představu o tom, jaké úlohy $\mathrm{v}$ jakých kolektivech fungují lépe a jaké lze např́íklad pro určité skupiny modifikovat co do obtížnosti. $V$ roce 2021 budeme $\mathrm{v}$ rámci druhé pilotáže únikové hry od návštěvníků formou dotazníku sbírat data vypovídající o jejich postojích $k$ jazykové diverzitě ve třech momentech - a) před uvedením do hry, b) po skončení hry a c) po delší době od absolvování hry. Mezi bod b) a c) jako proměnnou zařadíme doprovodný materiál shrnující, co všechno o jazycích a jejich mluvčích během řešení úkolů návštěvníci objevili, který bude pro školní kolektivy obohacen o pracovní list pro žáky a metodický list pro učitele umožňující následnou reflexi tohoto tématu ve třídě.

\section{Závěr}

Předložená studie demonstrovala, jak lze vývoj v oblasti lingvistických teorií a dokumentace světových jazyků transformovat do popularizačně-vzdělávacího obsahu určeného žákům základních a středních škol prostřednictvím výstavy s gamifikačními prvky, které vycházejí z teoretických principů zážitkového učení. Kinestetické, audiovizuální a interaktivní prvky v rámci expozice i gamifikace únikovou hrou se dynamickým zprostředkováním prožitku a vyžadováním různé míry participace ukázaly být vhodnou formou pro zpř́stupnění ",angažovaných" témat, jako je ochrana jazykové diverzity.

\section{Použité zdroje}

ABBOTT, Daisy, 2019. Game-based learning for postgraduates: an empirical study of an educational game to teach research skills. Higher Education Pedagogies. 4(1), 80-104.

ACHIAM, Marianne, Michael MAY a Martha MARANDINO, 2014. Affordances and distributed cognition in museum exhibitions. Museum 
Management and Curatorship. 29(5), 461-481.

ALLEN, Sue a Joshua GUTWILL, 2004. Designing With Multiple Interactives: Five Common Pitfalls. Curator: The Museum Journal. 47(2), 199-212.

BOGOST, Ian, 2014. Why Gamification Is Bullshit. In: Steffen P. WALZ and Sebastian DETERDING (eds.), The Gameful World. Approaches, Issues, Applications, s. 65-79

COMRIE, Bernard, 2013. Numeral Bases. In: Matthew DRYER a Martin HASPELMATH eds., The World Atlas of Language Structures Online. Leipzig: Max Planck Institute for Evolutionary Anthropology [online] [vid. 2020-10-20]. Dostupné z http://wals.info/chapter/131

DETERDING, Sebastian, Dan DIXON, Rilla KHALED a Lennart NACKE, 2011. From game design elements to gamefulness: defining "gamification". In: Proceedings of the 15th International Academic MindTrek Conference on Envisioning Future Media Environments - MindTrek '11. Tampere, Finland: ACM Press, s. 9-15

EVANS, Nicholas, 2001. The last speaker is dead - long live the last speaker! In: Paul NEWMAN a Martha RATLIFF, ed. Linguistic Fieldwork. Cambridge: Cambridge University Press, s. 250281. ISBN 978-0-521-66049-5.

EVANS, Nicholas a Stephen C. LEVINSON, 2009. The myth of language universals: Language diversity and its importance for cognitive science. Behavioral and Brain Sciences. 32(05), 429-492.

GIBSON, James J., 1979. The ecological approach to visual perception. Hillsdale, NJ: Lawrence Erlbaum Associates.

HARMON, David a Jonathan LOH, 2018. Congruence Between Species and Language Diversity. In: David HARMON a Jonathan LOH The Oxford Handbook of Endangered Languages. Oxford: Oxford University Press, s. 658-682. ISBN 978-0-19-061002-9.

LAKOFF, George a Mark JOHNSON, 1980. Metaphors we live by. Chicago (IL): University of Chicago Press. ISBN 978-0-226-47099-3.
LEGAKI, Nikoletta-Zampeta, Nannan XI, Juho HAMARI, Kostas KARPOUZIS a Vassilios ASSIMAKOPOULOS, 2020. The effect of challenge-based gamification on learning: An experiment in the context of statistics education. International Journal of Human-Computer Studies. 144, 102496.

LEWIS, M. Paul a Gary F. SIMONS, 2010. Assessing endangerment: Expanding Fishman's GIDS. Romanian Review of Linguistics. 55(2), 18, 103-120.

KIM, Sangkyun, Kibong SONG, Barbara LOCKEE a John BURTON, 2018. Gamification in learning and education: enjoy learning like gaming. Cham: Springer. Advances in game-based learning. ISBN 978-3-319-47283-6.

KOLB, David A., 2015. Experiential learning: experience as the source of learning and development. Second edition. Upper Saddle River, New Jersey (NJ): Pearson Education, Inc. ISBN 978-0-13-389240-6.

NICHOLSON, Scott, 2015. A RECIPE for Meaningful Gamification. In: Lincoln C. WOOD a Torsten REINERS, eds. Gamification in Education and Business, New York: Springer. 1-20.

NICHOLSON, Scott, 2012. Strategies for meaningful gamification: Concepts behind transformative play and participatory museums. Presented at Meaningful Play 2012. Lansing, Michigan. Dostupné z: http://scottnicholson.com/pubs/meaningfulstrategies.pdf

NÚNEZ, Rafael E. a Eve SWEETSER, 2006. With the Future Behind Them: Convergent Evidence From Aymara Language and Gesture in the Crosslinguistic Comparison of Spatial Construals of Time. Cognitive Science. 30(3), 401-450.

OVERMEER, Marjolein, 2019. Bezoek aan de educatieve tentoonstelling 'Wie ben ik, wie was jij?' [online] Nemo Kennislink. [vid. 2020-03-29]. Dostupné z: https://www.nemokennislink.nl/ publicaties/bronnen-jagen-in-het-nationaal-archief/?news_letter=true\&utm_ medium=email\&utm_campaign= 
NEMO+Kennislink+Nieuwsbrief $+8+$ februari+2019+-+Toch+geen+meter+ extra+zeespiegelstijging\&utm_content=NEMO+Kennislink+Nieuwsbrief/

PASHLER, Harold, Mark MCDANIEL, Doug ROHRER a Robert BJORK, 2008. Learning Styles: Concepts and Evidence. Psychological Science in the Public Interest. 9(3), 105-119.

PLASS, Jan L., Richard E. MAYER a Bruce D. HOMER, ed., 2020. Handbook of Game-based Learning. Cambridge (MA): The MIT Press. ISBN 978-0-262-04338-0.

PLASS, Jan L., Bruce D. HOMER, Richard E. MAYER a Charles K. KINZER, 2020. Theoretical Foundations of GameBased and Playful Learning. In: Jan L. PLASS, Richard E. MAYER, a Bruce D. HOMER, eds., Handbook of Game-based Learning. Cambridge (MA): The MIT Press, 3-24.

SIMON, Nina, 2010. The Participatory Museum. Santa Cruz (CA): Museum 2.0.

SKUTNABB-KANGAS, Tove a David HARMON, 2017. Biological diversity and language diversity: parallels and differences. In: Hermine PENZ a Alwin
FILL, ed. The Routledge Handbook of Ecolinguistics. New York (NY): Routledge, s. 11-25.

STEHLÍK, Michal. 2018. Muzea uprostřed „tekutého světa". Muzeum: Muzejní a vlastivědná práce. 56 (2), 34-39.

VELDKAMP, Alice, Liesbeth VAN DE GRINT, Marie-Christine KNIPPELS a Wouter VAN JOOLINGEN, 2020. Escape Education: A Systematic Review on Escape Rooms in Education [online]. preprint. [vid. 2020-10-24]. Dostupné z: doi:10.20944/preprints202003.0182.v1 VERGO, Peter, ed., 1989. The New Museology. London: Reaktion Books.

WANČOVÁ, Nina. 2018. Využívání nových médií, technologií a moderních prezentačních postupů $\mathrm{v}$ českých muzeích. Muzeum: Muzejní a vlastivědná práce. 56 (1), 24-36.

WANG, Meiqian a Xudong ZHENG, 2020. Using Game-Based Learning to Support Learning Science: A Study with Middle School Students. The Asia-Pacific Education Researcher [online]. [vid. 2020-10-24]. Dostupné z: doi:10.1007/s40299-020-00523-z 